\title{
Effects of Blue Light and Red Light on Kidney Bean Plants Grown under Combined Radiation from Narrow-Band Light Sources
}

\author{
Hiromichi HANYU and Kazuhiro SHOJI \\ Biology Department, Central Research Institute of Electric Power Industry, Abiko 270-1194, Japan
}

(Received June 15, 1999)

\begin{abstract}
Kidney bean (Phaseolus vulgaris L.) plants were grown at different levels of blue and red light under broad-spectrum radiation over $12 \mathrm{~d}$. Using four kinds of narrow-band fluorescent lamps, blue or red light was increased at the same levels of photosynthetic photon flux density ( $\left.100 \mu \mathrm{mol} \mathrm{m}^{-2} \mathrm{~s}^{-1}\right)$ and red to far-red photon flux ratio ( $R$ : FR ; 1.1). Increases in both blue and red light caused increases in total dry matter, but also quite different dry matter distribution. Increasing blue light did not have a significant influence on leaf area but caused a large decrease in stem length. On the other hand, increasing red light caused both increases in leaf area and a small, but consistent, increase in stem length. The data suggest that increases in total dry matter are due to increases in dry matter production per unit leaf area in the case of increasing blue light, and on the other hand, due to increases in leaf area in the case of increasing red light. Besides the growth response caused by R : FR, the results indicate that increases in blue light cause great inhibition of stem extension and thickening of leaf, while increases in red light at constant $R$ : FR accelerates both stem extension and leaf expansion without modifying leaf thickness.
\end{abstract}

\section{INTRODUCTION}

The covering materials of greenhouses and the artificial lamps used therein influence the spectral composition or quality of the radiation to which cultivated plants are exposed (Takano, 1975; Hughes et al., 1984). Long-term exposure (days or weeks) to radiation of different qualities has been reported to bring some changes in plant growth and morphology (Warrington and Michell, 1976 ; Mortensen and Str $\phi$ mme, 1987 ; Rajapakse and Kelly, 1995). These results suggest that the quality of product can be improved using optimal radiation qualities. The data, moreover, appear to show that acceleration of stem extension is caused by radiation with a low red to far-red photon flux ratio $(R: F R)$ and radiation with a high $\mathrm{R}$ : FR but little blue light, although the studies were examined under different spectral conditions. However, these studies are not adequate to give a common view on the spectral effects of radiation on product quality, because the spectral effects remained undefined excluding changes in stem extension.

Experiments to date on short-term exposure (minutes or hours) to red, far-red or blue light showed that stem extension in seedlings is controlled individually by both phytochromes and the blue-light photoreceptors (Jose, 1977; Cosgrove, 1981; Gaba et al., 1984; Casal and Smith, 1988; Kiegel and Cosgrove, 1991). Decreases in R: FR have been shown to cause acceleration of stem extension and inhibition of branching in several plants grown under 
broad-spectrum radiation (Smith, 1982). The long-term effects of $R: F R$ on plants have been also examined by supplementing far-red light at the same photosynthetic photon flux density (PPFD, 400-700 nm) (Murakami et al., 1991 ; Hanyu et al., 1996). Increasing far-red light with constant red light has been shown to cause stimulation of stem extension and leaf expansion and to increase dry matter (DM) and dry matter partitioning to stems in kidney bean (Hanyu et al., 1996). The previous studies, however, do not show whether increases in red light could modify plant growth and morphology when maintaining PPFD, R: FR and phytochrome photoequilibrium ( $\mathrm{Pfr} / \mathrm{P})$, the fraction of total phytochrome in the active state, constant.

On the other hands, there are not many studies on the long-term effects of blue light on plants compared with those of R: FR. The effects of blue light on stem extension have been examined in several species including tomato and ryegrass by means of adding blue light to background light (Thomas and Dickinson, 1979; Casal and Alvarez, 1988; Wheeler et al., 1991). As a result, the stem extension rates have been shown to decrease with increasing blue light in all of those species. Similarly, increases in blue light containing broad-spectrum radiation have been shown to cause inhibition of stem extension and reductions in the dry matter partitioning to stems at the same total DM in kidney bean plants (Maas et al., 1995). When soybean, sorghum and pepper plants were grown under blue-deficient light sources compared to plants grown under supplemental blue light sources, acceleration of stem extension and reductions in DM have been shown to occur (Britz and Sager, 1990 ; Brown et al., 1995). Thus the previous studies do not detail the long-term effects of blue light on all plant parts but only examine the effects on stem extension, but increases in blue light appear certainly to cause changes in DM and dry matter partitioning. Furthermore, it was suggested that the blue-light photoreceptors acted as a photon flux counter (MacLaren and Smith, 1978 ; Ritter et al., 1981), and played an important role in plant response to radiation quantity as well as radiation quality, due to its co-action with the other photoreceptor, phytochromes (Mohr, 1994). For this reason, increases in blue light also probably cause morphological changes in leaves and stems as well as in the case of the shade-avoidance reaction caused by R: FR perception (Smith, 1982).

In this study, we examined the long-term effects of increasing blue light and red light on growth and morphology in kidney bean plants grown under broad-spectrum radiation. The aim was to determine whether blue light could modify leaf expansion and thickness, DM and dry matter partitioning and also whether red light could affect growth and morphology, when PPFD and R: FR were kept constant. Because the blue-light photoreceptors show no spectral activity when subjected to red light (Hsiao et al., 1973 ; Brinkmann and Senger, 1978 ; Lipson et al., 1984), the photoreceptors are considered not to be directly involved in the growth changes induced by increasing red light at the same PPFD. Accurate spectral regulation, which would not allow photoresponses to $\mathrm{R}$ : FR, might give us a clearer understanding of the effects of blue or red light. Therefore, in order to vary blue or red light while keeping PPFD and R : FR constant, four different narrow-band fluorescent lamps were applied.

\section{MATERIALS AND METHODS}

Plant and cultivation. Kidney bean (Phaseolus vulgaris L. cv. Kentucky Wonder) seeds soaked overnight in running water, were placed on wet paper towels in plastic boxes and germinated in the dark at $25^{\circ} \mathrm{C}$. Two days later, the seeds, with radicles grown up to $1-2 \mathrm{~cm}$, were transferred into urethane cube media in plastic trays. They were grown in the room kept at $23^{\circ} \mathrm{C}$ under a $12-\mathrm{h}$ white light photoperiod $\left(110 \mu \mathrm{mol} \mathrm{m}^{-2} \mathrm{~s}^{-1}\right.$ of PPFD) for $7 \mathrm{~d}$. Seedlings of approximately equal size, having developed the first two leaves (stem length $6 \mathrm{~cm}$; leaf area 

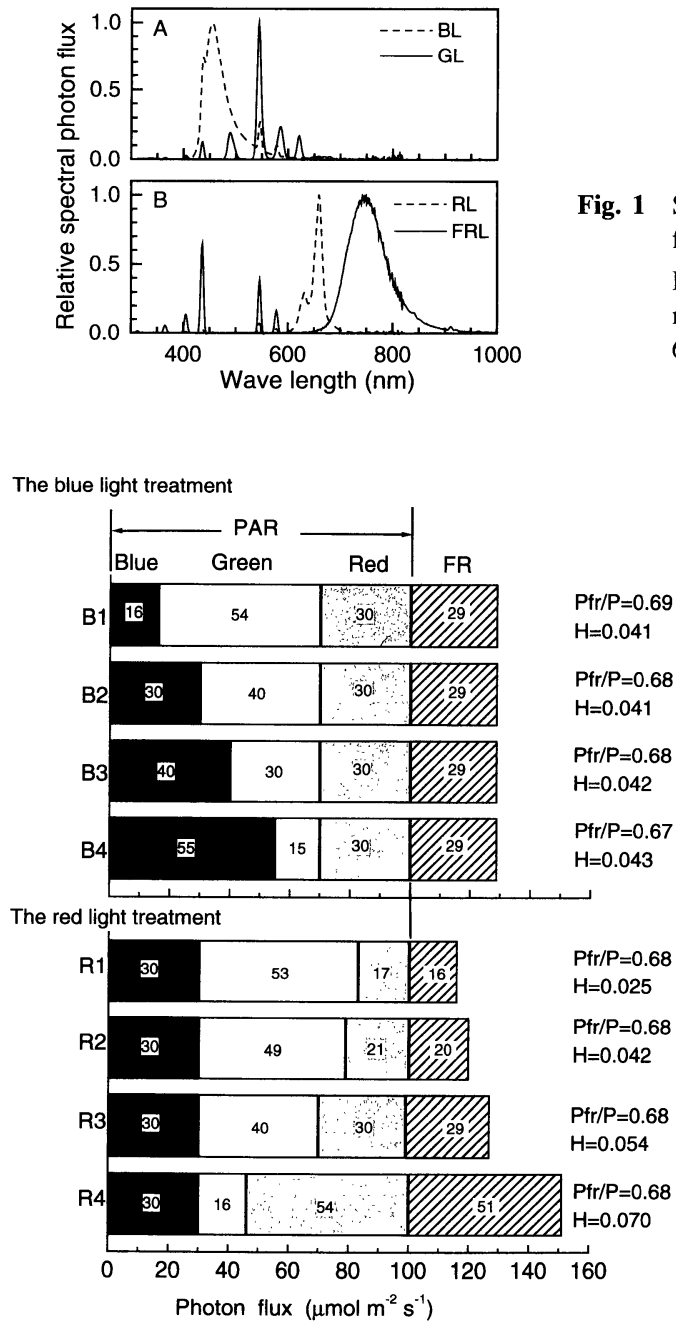

Fig. 1 Spectral photon distributions of monochromatic fluorescent lamps.

Relative spectral photon flux of each lamp was normalized to 1.0 at $454 \mathrm{~nm}(\mathrm{BL}), 544 \mathrm{~nm}(\mathrm{GL})$, $659 \mathrm{~nm}(\mathrm{RL})$ or $749 \mathrm{~nm}$ (FRL).

$40 \mathrm{~cm}^{2}$; dry weight $0.2 \mathrm{~g}$ ), were transplanted onto hydroponic beds $(90 \times 60 \times 20 \mathrm{~cm})$ placed in four similar growth chambers (Yokohama Kiko Co., Yokohama, Japan). The plants were spectrally treated for $12 \mathrm{~d}$ in growth chambers, kept at $25^{\circ} \mathrm{C}$ in an air-conditioned room under a 16-h photoperiod. Plants were grown hydroponically using an Otsuka-house A solution (Otsuka Chemical Co., Japan), containing (in $\mathrm{mg} \mathrm{L}^{-1}$ ) $23 \mathrm{NH}_{4}, 223 \mathrm{NO}_{3}, 120 \mathrm{P}_{2} \mathrm{O}_{5}, 60 \mathrm{~K}_{2} \mathrm{O}_{3}$, $30 \mathrm{CaO}_{2}, 75 \mathrm{MgO}, 1.5 \mathrm{MnO}, 1.5 \mathrm{~B}_{2} \mathrm{O}$ and $2.7 \mathrm{Fe}$. The electrical conductivity of the hydroponic solution was adjusted to $1.2 \mathrm{dS} \mathrm{m}^{-1}$ initially and maintained near $2.4 \mathrm{dS} \mathrm{m}^{-1}$ from the fifth day after transplanting the seedlings. The $\mathrm{pH}$ was maintained near 6.0.

Light sources and spectral treatments. Plants were exposed to mixed radiation from four-different 40-W fluorescent lamps (FLR1250T6 EB, EG, R and ER, Yokohama Kiko Co. and Nippo Electric Co., Hiratsuka, Japan), blue (BL), green (GL), red (RL) and far-red (FRL) lamps (Fig. 1). The lamps were equipped with power units (FDP-2001, Nippo Electric Co.) to accurately determine blue $(400-500 \mathrm{~nm})$, green $(500-600 \mathrm{~nm})$, red $(600-700 \mathrm{~nm})$ and far-red $(700-800 \mathrm{~nm})$ photon flux. The inner walls of the growth chambers were covered with smooth aluminum plates (the reflectivity was $75 \%$ or greater) to reduce photon flux deviation. Lamps of each type were placed on the ceiling and upper part of the walls alternately to 
improve the uniformity of the spectral photon distribution.

Plants received $100 \mu \mathrm{mol} \mathrm{m}^{-2} \mathrm{~s}^{-1}$ of PPFD in two spectral treatments while R: FR was kept constant at 1.1 , because the species have been shown to grow and flower at $78 \mu \mathrm{mol} \mathrm{m}^{-2}$ $\mathrm{s}^{-1}$ of PPFD (Hanyu and Shoji, 1995). The blue photon flux in the blue light treatment was determined by offsetting the increase in blue light with a decrease in green light at a $30 \mu \mathrm{mol}$ $\mathrm{m}^{-2} \mathrm{~s}^{-1}$ red photon flux (Fig. 2). The red photon flux in the red light treatment was determined by maintaining the blue light at $30 \mu \mathrm{mol} \mathrm{m}^{-2} \mathrm{~s}^{-1}$ or a total of red and green light at 70 $\mu \mathrm{mol} \mathrm{m} \mathrm{m}^{-2} \mathrm{~s}^{-1}$. Simultaneously, the far-red photon flux was changed with the red photon flux (Fig. 2). The blue light treatment and red light treatment were repeated three times, respectively. Spectral photon distribution was measured using a spectroradiometer (MSR 7000, Opto Research, Tokyo, Japan) to calculate the blue, green and red photon contents of PPFD (B : PPFD, G: PPFD, R : PPFD) and R: FR. Photosynthetic photon flux was obtained using a quantum sensor (LI-190SB, Li-Cor Inc., Lincoln, U.S.A.). Photon content targets were achieved by repeating the determination of PPFD and spectral photon distribution, calculation of the photon contents and output adjustment of the narrow-band light sources.

The radiation from BL showed a maximum peak at $454 \mathrm{~nm}$ (Fig. 1A). The radiation consisted of a photon flux of $78 \%$ blue light and only $3 \%$ red and far-red light. In contrast, the spectral peaks for RL and FRL were observed at 659 and $749 \mathrm{~nm}$, respectively (Fig. 1B). The radiation from RL contained $92 \%$ red light and only $1 \%$ blue light, while that from FRL consisted of $71 \%$ far-red light and 5\% blue light in the photon flux. Phytochrome photoequilibrium $(\mathrm{Pfr} / \mathrm{P})$, the fraction of total phytochrome in the active state, and phytochrome cycling rate $(H)$, the concentrations of intermediates in the photoconversion between $\mathrm{Pr}$ and $\mathrm{Pfr}$, were determined from our spectral photon distribution data using extinction coefficients of phytochrome extracted from oats and rye (Kelly and Lagarias, 1985 ; Lagarias et al., 1987), because there was a possibility that Pfr/P might be unequal despite R : FR being kept constant in both spectral treatments. Calculated values for $\mathrm{Pfr} / \mathrm{P}$ decreased by 0.02 from 0.69 with increasing blue light and increased by less than 0.01 from 0.68 with increasing red light as shown in Fig. 2. Besides, calculated values for $H$ hardly increased as blue light increased, but increased by 0.045 as red light increased while keeping R : FR constant.

Plant growth measurements and analyses. Plants were harvested $12 \mathrm{~d}$ after the start of spectral treatments and separated into leaves, stems and roots. DM was obtained by drying the separated materials in a forced-air oven for $7 \mathrm{~d}$ at $60^{\circ} \mathrm{C}$. Leaves (minimum size of leaf length was $0.7 \mathrm{~cm}$ ) and nodes (minimum size of internode length was $0.3 \mathrm{~cm}$ ) were counted and stem lengths including the hypocotyls were measured. The total leaf area (LA) as well as the length and width of the largest leaf were measured using our special image-processor capable of detecting an area of $0.03 \mathrm{~cm}^{2}$. The mean leaf area (LA/leaf number) and specific leaf area (SLA ; LA/leaf DM), as well as specific stem dry matter (SSD; stem DM/stem length) were calculated to compare differences in morphology in leaves and stems.

All of the growth parameters were subjected to one-way analysis of variance ( $n=10$, three replications) and the significant differences between means were analyzed according to Tukey's multiple range test $(p<0.05)$.

Growth parameters were also classified to clarify the differences between the effects caused by the blue and the red light treatment. $\mathrm{BE}_{i}$ and $\mathrm{RE}_{i}$, the degrees to which the blue and the red light treatment influenced each growth parameter $i$, were determined as follows:

$$
\mathrm{BE}_{i}=\left(1-M_{i}(\mathrm{~B} 4) / M_{i}(\mathrm{~B} 1)\right) \cdot 100(\%), \quad \mathrm{RE}_{i}=\left(1-M_{i}(\mathrm{R} 4) / M_{i}(\mathrm{R} 1)\right) \cdot 100(\%),
$$

where $M_{i}(\mathrm{~B} 4)$ and $M_{i}(\mathrm{~B} 1)$ are the mean values of growth parameter observed at the maximum (B4) and the minimum (B1) levels of blue light respectively, and $M_{i}(\mathrm{R} 4)$ and $M_{i}(\mathrm{R} 1)$ are the mean values of growth parameter observed at the maximum (R4) and the minimum (R1) levels 
of red light respectively. An increase in $\mathrm{BE}_{i}$ and $\mathrm{RE}_{i}$ is shown with a "+" and decrease with a "-." When the absolute value of $\mathrm{RE}_{i}$ was less than half of the absolute value of $\mathrm{BE}_{i}$, parentheses were added to the "+" or the "-."

\section{RESULTS}

\section{Spectral treatments and radiation quality}

Effects of the blue light treatment. The levels of blue light $\left(16,30,40\right.$ and $55 \mu \mathrm{mol} \mathrm{m}^{-2}$ $\mathrm{s}^{-1}$ ) significantly affected the DM for each plant and dry matter partitioning between leaves, stems and roots (Fig. 3). As blue light increased, leaf DM and root DM increased, while stem DM reduced. As a result, total DM was greater when blue light was stronger. Dry matter partitioning ratio of leaves increased and that of stems decreased with increasing blue light. Dry matter partitioning ratio of roots was $2 \%$ greater at $55 \mu \mathrm{mol} \mathrm{m}^{-2} \mathrm{~s}^{-1}$ blue light than that at $16 \mu \mathrm{mol} \mathrm{m}^{-2} \mathrm{~s}^{-1}$ blue light. Consequently, higher levels of blue light suppressed dry matter accumulation in stems and promoted dry matter accumulations in leaves and roots, with dry matter partitioning changing as DM changed.

The growth parameters of leaves, i.e. LA, LA per leaf number and ratio of leaf length to leaf width, were not significantly affected by blue light levels (Table 1). However, SLA (the larger the SLA, the smaller the leaf thickness) decreased significantly as blue light increased. On the other hand, the growth parameters of stems, except node numbers, were significantly

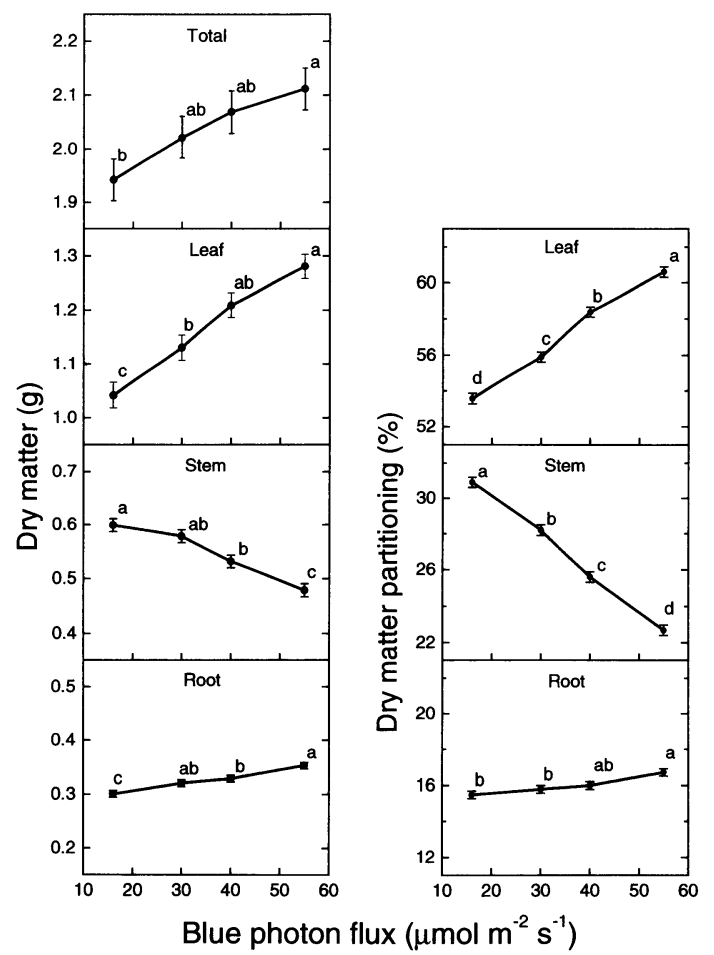

Fig. 3 Dependence of DM and dry matter partitioning for each portion of leaf, stem and root in kidney bean plants on blue photon flux.

Data are the means from three replicate experiments with SE, the plants harvested $12 \mathrm{~d}$ after the start of the blue light treatment. Letters indicate significance at the $p<0.05$ level according to Tukey's multiple range test. 
Table 1 Effects of the blue light treatment on growth parameters of kidney bean plants.

\begin{tabular}{|c|c|c|c|c|}
\hline & \multicolumn{4}{|c|}{ B : PPFD } \\
\hline & 0.16 & 0.30 & 0.40 & 0.55 \\
\hline \multicolumn{5}{|l|}{ Leaf } \\
\hline Number of leaves & $16.5 \mathrm{a}$ & $16.3 \mathrm{a}$ & $15.8 \mathrm{ab}$ & $15.4 \mathrm{~b}$ \\
\hline Leaf length to width ratio & $1.58 \mathrm{a}$ & $1.52 \mathrm{a}$ & $1.49 \mathrm{a}$ & $1.50 \mathrm{a}$ \\
\hline Total leaf area, LA $\left(\mathrm{cm}^{2}\right)$ & $757 \mathrm{a}$ & $764 \mathrm{a}$ & $765 a$ & $728 \mathrm{a}$ \\
\hline LA/No. of leaves $\left(\mathrm{cm}^{2}\right)$ & $46 \mathrm{a}$ & $47 \mathrm{a}$ & $49 \mathrm{a}$ & $48 \mathrm{a}$ \\
\hline SLA $\left(\mathrm{cm}^{2} \mathrm{~g}^{-1}\right)$ & $727 \mathrm{a}$ & $676 \mathrm{~b}$ & $632 c$ & $568 \mathrm{~d}$ \\
\hline \multicolumn{5}{|l|}{ Stem } \\
\hline Number of nodes & $10.6 \mathrm{a}$ & $10.6 \mathrm{a}$ & $10.5 \mathrm{a}$ & $10.3 \mathrm{a}$ \\
\hline Stem length $(\mathrm{cm})$ & $151 \mathrm{a}$ & $127 \mathrm{~b}$ & $101 \mathrm{c}$ & $66 \mathrm{~d}$ \\
\hline $\operatorname{SSD}\left(\mathrm{mg} \mathrm{cm}^{-1}\right)$ & $3.97 \mathrm{~d}$ & $4.50 \mathrm{c}$ & $5.47 \mathrm{~b}$ & $7.43 \mathrm{a}$ \\
\hline
\end{tabular}

The levels of blue light are shown as B : PPFD. Data are the means from three replicate experiments, the plants harvested $12 \mathrm{~d}$ after the start of the blue light treatment. Letters indicate significance at the $p<0.05$ level accoring to Tukey's multiple range test.

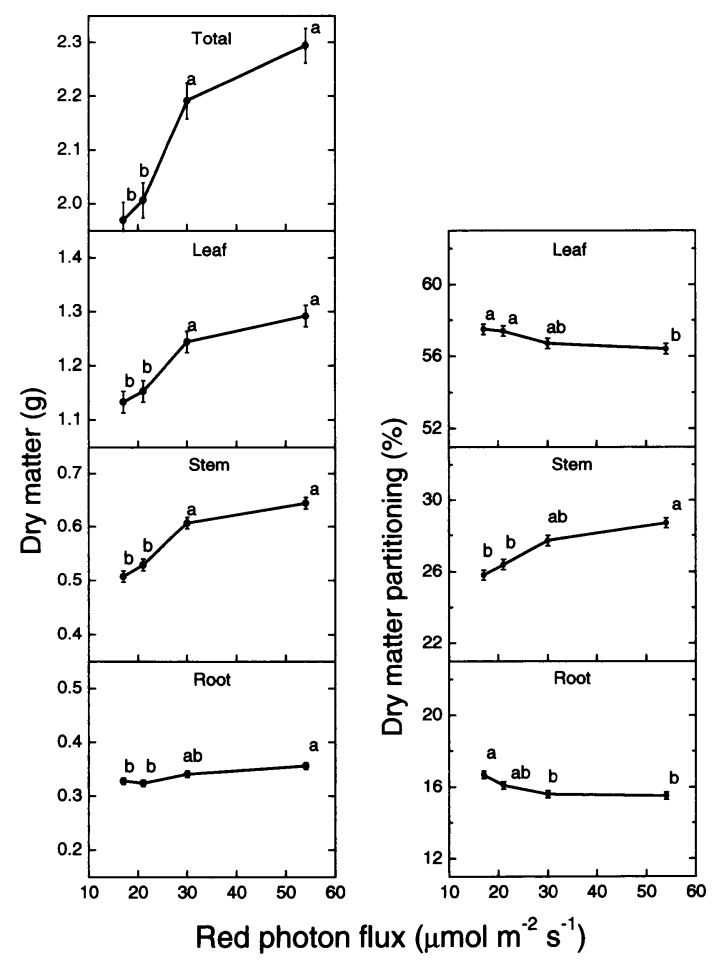

Fig. 4 Dependence of DM and dry matter partitioning for each portion of leaf, stem and root in kidney bean plants on red photon flux.

Data are the means from three replicate experiments with SE, the plants harvested $12 \mathrm{~d}$ after the start of the red light treatment. Letters indicate significance at the $p<0.05$ level according to Tukey's multiple range test.

affected by blue light levels (Table 1). Stem length decreased to less than half as blue light increased, while SSD increased.

Effects of the red light treatment. DM and dry matter partitioning were significantly 
influenced by red light levels $\left(17,21,30\right.$ and $\left.54 \mu \mathrm{mol} \mathrm{m}^{-2} \mathrm{~s}^{-1}\right)$ (Fig. 4). As red light increased, leaf DM and stem DM increased. Root DM was $9 \%$ greater at $54 \mu \mathrm{mol} \mathrm{m}^{-2} \mathrm{~s}^{-1}$ of red light, compared with that at $17 \mu \mathrm{mol} \mathrm{m}^{-2} \mathrm{~s}^{-1}$ red light. Therefore, total DM was greater when red light was stronger. As the red light level increased, dry matter partitioning to stems increased while dry matter partitioning to leaves and to roots decreased. Thus, higher levels of red light promoted dry matter accumulation in stems, while with dry matter accumulation in leaves and roots, the dry matter partitioning did not change as in the case of DM itself.

Red light levels significantly affected the growth parameters of leaves, i.e. LA and LA per leaf number (Table 2). The parameters were greater at $54 \mu \mathrm{mol} \mathrm{m}^{-2} \mathrm{~s}^{-1}$ red light compared with those at $17 \mu \mathrm{mol} \mathrm{m}^{-2} \mathrm{~s}^{-1}$ red light. However, leaf number, ratio of leaf length to leaf width and SLA were not significantly different between red light levels. Growth parameters of stems, except for stem length, were not affected by red light levels (Table 2).

Comparison of the effects of the blue light and the red light treatments. Concerning the effects of the two spectral treatments, growth parameters were classified based on defined degrees and polarities of effects described in the section of MATERIALS AND METHODS (Table 3).

Table 2 Effects of the red light treatment on growth parameters of kidney bean plants.

\begin{tabular}{|c|c|c|c|c|}
\hline & \multicolumn{4}{|c|}{$\mathrm{R}:$ PPFD } \\
\hline & 0.17 & 0.21 & 0.30 & 0.54 \\
\hline \multicolumn{5}{|l|}{ Leaf } \\
\hline Number of leaves & $15.8 \mathrm{a}$ & $15.9 \mathrm{a}$ & $16.3 \mathrm{a}$ & $16.4 \mathrm{a}$ \\
\hline Leaf length to width ratio & $1.51 \mathrm{a}$ & $1.43 \mathrm{a}$ & $1.50 \mathrm{a}$ & $1.51 \mathrm{a}$ \\
\hline Total leaf area, LA $\left(\mathrm{cm}^{2}\right)$ & $731 \mathrm{~b}$ & $745 \mathrm{~b}$ & $816 \mathrm{a}$ & $851 \mathrm{a}$ \\
\hline LA/No. of leaves $\left(\mathrm{cm}^{2}\right)$ & $47 \mathrm{~b}$ & $47 \mathrm{~b}$ & $50 \mathrm{a}$ & $52 \mathrm{a}$ \\
\hline SLA $\left(\mathrm{cm}^{2} \mathrm{~g}^{-1}\right)$ & $647 \mathrm{a}$ & $645 \mathrm{a}$ & $657 \mathrm{a}$ & $659 \mathrm{a}$ \\
\hline \multicolumn{5}{|l|}{ Stem } \\
\hline Number of nodes & $10.5 \mathrm{a}$ & $10.5 \mathrm{a}$ & $10.6 \mathrm{a}$ & $10.7 \mathrm{a}$ \\
\hline Stem length $(\mathrm{cm})$ & $114 \mathrm{~b}$ & $117 \mathrm{~b}$ & $135 \mathrm{a}$ & $138 \mathrm{a}$ \\
\hline $\operatorname{SSD}\left(\mathrm{mg} \mathrm{cm}^{-1}\right)$ & $4.50 \mathrm{a}$ & $4.59 \mathrm{a}$ & $4.51 \mathrm{a}$ & $4.69 \mathrm{a}$ \\
\hline
\end{tabular}

The levels of red light are shown as R: PPFD. Data are the means from three replicate experiments, the plants harvested $12 \mathrm{~d}$ after the start of the red light treatment. Letters indicate significance at the $p<0.05$ level according to Tukey's multiple range test.

Table 3 Classified effects of two spectral treatments on growth parameters of kidney bean plants.

\begin{tabular}{cccl}
\hline Group & $\begin{array}{c}\text { Blue light } \\
\text { treatment }\end{array}$ & $\begin{array}{c}\text { Red light } \\
\text { treatment }\end{array}$ & \multicolumn{1}{c}{ Growth parameter } \\
\hline I & + & + & Total DM \\
II & + & $(-)$ & Dry matter partitioning (leaf, root) \\
III & - & $(+)$ & Dry matter partitioning (stem), Stem length \\
IV & + & NS & SSD \\
V & - & NS & SLA, No. of leaves \\
VI & NS & + & LA, LA/No. of leaves \\
VII & NS & NS & Leaf length: width ratio, No. of nodes \\
\hline
\end{tabular}

Degrees of effects were obtained as ratios of "the mean value at the maximum level" to "that at the minimum level" of the blue or red light content. Increase is shown with a "+" and decrease with a "-." When the absolute value of increase or decrease of the red light treatment in percentage is less than $1 / 2$ of the blue light treatment, it is shown with a " $(+)$ " or a "(-)" respectively. "NS" indicates no significant difference. 
Total DM increased by 9 and 16\%, respectively, with an increase in blue and red light (Group I). The changes in dry matter partitioning of the leaf, stem and root ( 8 to $27 \%$ ) caused by the blue light treatment were twice as large as or larger than those ( 2 to $9 \%$ ) brought about by the red light treatment. The former changes were opposite in polarity to the latter ones (Groups II and III). Stem length decreased by $56 \%$ as blue light increased, and increased by $21 \%$ as red light increased. This was similar to that of dry matter partitioning to stems, showing that stem length belonged to Group III. SSD increased by $87 \%$ as blue light increased but remained unchanged as red light increased (Group IV). Leaf number and SLA were influenced only by the blue light treatment (Group V), while LA and LA per leaf number showed only red light effects (Group VI). The degrees of effects were -7 and $-22 \%$ in the former and +16 and $+11 \%$ in the latter. Neither the ratio of leaf length to leaf width nor node number was affected by the spectral treatments (Group VII).

\section{DISCUSSION}

Spectral photon flux from the BL, RL and FRL used were strongest at 454, 659 and 749 $\mathrm{nm}$, respectively. The first one hardly contained red and far-red light and the other two contained little blue light (Fig. 1). Accordingly, it is believed that photoresponses in our spectral treatments are caused by blue light or red and/or far-red light. Under high-irradiance and broad-spectrum radiation, stem extension rates are thought to be related to the values for $\mathrm{Pfr} / \mathrm{P}$ which are mainly dependent on $\mathrm{R}$ : FR, decreases in Pfr/P accelerating stem extension in various plants (Smith, 1982). In each spectral treatment, R : FR levels were maintained equivalent and changes in $\mathrm{Pfr} / \mathrm{P}$ were less than 0.02 (Fig. 2). Acceleration of stem extension is estimated to be $3 \%$ in kidney bean (Hanyu et al., 1996), when values for $\mathrm{Pfr} / \mathrm{P}$ decrease by 0.02. This shows that differences in $\mathbf{P f r} / \mathbf{P}$ hardly contribute to changes in stem extension, regardless of the spectral treatment. Besides decreases in $\mathrm{Pfr} / \mathrm{P}$, decreases in $H$ at constant $\mathrm{Pfr} / \mathrm{P}$ may also promote logarithmically stem extension (Gaba and Black, 1985). The calculated $H$, however, hardly changed by increasing blue light. On the other hand, the calculated $H$ slightly increased by increasing red light. Because increases in $H$ cause inhibition of stem extension, acceleration of stem extension caused by increasing red light cannot be attributed to differences in $\boldsymbol{H}$.

The effects of blue light on stem extension have been reported previously, although many of these studies were short-term and used seedling hypocotyls or epicotyls (Thomas and Dickinson, 1979; Cosgrove, 1981 ; Casal and Smith, 1988). These results have shown one of the roles of the blue-light photoreceptors, where blue light acted to inhibit stem extension. In our blue light treatment, stem extension of kidney bean was strongly inhibited with increasing blue light (Table 1), suggesting that the long-term effects on the plant, as well as the short-term effects on seedlings, are mediated by the blue-light photoreceptors. Previous studies have also shown that inhibition of stem extension in seedlings was caused by continuous exposure to red light, mediated by phytochromes (Beggs et al., 1980). In the red light treatment R : FR was kept constant and in consequence $\mathrm{Pfr} / \mathrm{P}$ was approximately constant, but stem extension was accelerated as red light increased (Table 2). This shows that not all of the acceleration in stem extension can be explained by responses to R : FR or Pfr/P.

Several studies have examined the long-term effects of the differences in spectral distribution on growth including DM and LA under artificial lighting by commercially available lamps (Warrington and Michell, 1976; Maas et al., 1995) or natural radiation through trail spectral filters (Mortensen and Str $\not$ mme, 1987; Rajapakse and Kelly, 1995). The results indicate that plants grown under red-enriched light tend to produce more DM and LA than plants grown under blue-enriched light, although the extent of the effects are less than that on 
stem length. In our study, when both PPFD and R: FR were kept constant, increasing red light with constant blue light caused increases in total DM in proportion to LA (Fig. 4 and Table 2), showing good agreement with the results from the previous studies. On the other hand, increasing blue light with constant red light caused increases in the total DM but had no influence on LA (Fig. 3 and Table 1). The data indicate that dry matter production per unit leaf area in kidney bean does not change as red light increases but increases as blue light increases. The leaf of kidney bean has been reported to show higher reflectance and lower absorptivity and photosynthetic quantum yield in the green region rather than the blue region (Balegh and Biddulph, 1970). Although increases in blue light also caused significant increases in leaf thickness (Table 1), diffusive conductance of $\mathrm{CO}_{2}$ in the mesophyll has been demonstrated to increase as space in the mesophyll increases with leaf thickening (Holmgren, 1968). Besides, stomatal aperture has been shown to increase due to exposure to blue light (Hsiao et al., 1973; Sung and Takano, 1997). We cannot rule out the possibilities that such factors cause increases in dry matter production per unit leaf area.

As shown in Table 3, the growth parameters examined were classified based on the comparison of the blue light treatment effect with the red light treatment effect in order to understand the morphological significance of the blue light response. Each of growth parameters classified as Groups II-V was affected by the blue light treatment. Stem length and dry matter partitioning (Groups II and III) were influenced not only by the blue light treatment but also less by the red light treatment. Maas et al. (1995) have shown that increases in blue light did not affect total DM significantly but caused increases in dry matter partitioning to internodes at the expense of leaves in kidney bean. On the other hand, decreases in irradiance have been shown to trigger the reallocation of dry matter from the roots and leaves to the stems and petioles, including the production of thinner leaves (Simes and Pearcy, 1994). Thus, the effects of low irradiance on dry matter partitioning correspond to the effects of low blue light. As was suggested by Smith (1982), the shade-avoidance strategy of plants, is to mobilize all available carbohydrates and greatly increase stem extension at the expense of leaf expansion. It has been shown that decreases in $\mathrm{R}$ : FR causes an increase in the allocation of ${ }^{14} \mathrm{C}$-assimilates to petioles in clover at the expense of stolons and roots (Robin et al., 1992). In our experiment, reductions in blue light increased stem length and dry matter partitioning to stems, suggesting that the adaptation of kidney bean to shade condition is caused by blue-light response in addition to $\mathrm{R}$ : FR response. When red light increased, both dry matter partitioning and DM increased with regard to the stem but only DM increased with regard to the leaf and root. These results suggest that the red-light dependence in dry matter partitioning is dominated by stem extension.

LA and mean leaf area, the growth parameters related to leaf expansion (Group VI), were influenced by the red light treatment and not influenced by the blue light treatment. The fact that blue light has no effect on leaf length has been indicated also by Casal and Alvarez (1988). In the red light treatment, as R : FR was kept constant, the acceleration of leaf expansion can be reasonably attributed to increases in red and/or far-red light. SLA and SSD, leaf and stem morphology parameters (Groups IV and V), are not influenced by the red light treatment but by the blue light treatment. Our previous research (Hanyu et al., 1996) indicated that reducing $R$ : FR results in increased SLA and decreased SSD in the additional far-red light treatment. The results show that changes in SLA and SSD can be caused by increases in both blue light and additional far-red light. These morphological responses can be understood as shade-avoidance reaction (Smith, 1982), while the understandings of the red-light response are unclear because of unchanged SLA and SDL.

The findings obtained from this study provide some valuable insights into the photocontrol mechanisms of morphology in plants grown under broad-spectrum radiation. 
When PPFD and R : FR are kept constant, increasing blue light with constant red light did not have a significant influence on leaf expansion but caused notable inhibition of stem extension. On the other hand, increasing red light with constant blue light caused acceleration of both leaf expansion and stem extension. The degree to which increases in red light influenced stem extension, however, was less than that in the case of increasing blue light. Because the differences in $\mathrm{Pfr} / \mathrm{P}$ in each spectral treatment were small to cause the observed changes in stem extension, the results suggest that the blue light-induced changes are mediated by the blue-light photoreceptors and the red light-induced changes are not attributed to R : FR, but they are mediated by phytochromes. Increases in both blue and red light caused significant increases in total DM, but also quite different distribution of that DM. Increases in total DM appear to be due to increases in dry matter production per unit leaf area in the case of increasing blue light, and on the other hand, due to increases in LA in the case of increasing red light. Thus, reductions in blue light caused increases in stem length and dry matter partitioning to stems, and decreases in leaf thickness at the expense of leaves in kidney bean. The perception of blue-light levels, therefore, appear to cause the shade avoidance as well as the perception of R : FR by phytochromes. As a consequence, increasing blue light is believed to produce plants with thick leaves and hardy stems similar to the effects caused by decreasing the added-far-red light.

This study, however, did not confirm the interactions between enhanced blue light and red or far-red light on plant growth nor plant responses to red light at the same levels of far-red light. Further, photon flux response curves for the inhibition of hypocotyl extension have been reported to differ with regard to exposure to blue light and red light (Holmes and Schäfer, 1981), but whether the observed spectral effects are photon flux dependent was not examined. We plan to follow up on the still unresolved problems, and also study the long-term effects of spectral treatments on growth in short-stem plants.

\section{REFERENCES}

Balegh, S. E., Biddulph, O. 1970. The photosynthetic action spectrum of the bean plant. Plant Physiol. 46: $1-5$.

Beggs, C. J., Holmes, M. G., Jabben, M., Schäfer, E. 1980. Action spectra for inhibition of hypocotyl growth by continuous radiation in light and dark grown Sinapis alba L. seedlings. Plant Physiol. 66 : 615-618.

Brinkmann, G., Senger, H. 1978. The development of structure and function in chloroplasts of greening mutants of Scenedesmus. IV. Blue light dependent carbohydrate and protein metabolism. Plant Cell Physiol. 19 : 1427-1437.

Britz, S. J., Sager, J. C. 1990. Photomorphogenesis and photoassimilation in soybean and sorghum grown under broad spectrum or blue-deficient light sources. Plant Physiol. 94 : 448-454.

Brown, C. S., Schuerger, A. C., Sager, J. C. 1995. Growth and photomorphogenesis of pepper plants under red light-emitting diodes with supplemental blue or far-red lighting. J. Am. Soc. Hortic. Sci. 120 : 808-813.

Casal, J. J., Alvarez, M. A. 1988. Blue light effects on the growth of Lolium multiform Lam. leaves under natural radiation. New Phytol. $109: 41-45$.

Casal, J. J., Smith, H. 1988. The loci of perception for phytochrome control of internode growth in light-grown mustard: Promotion by low phytochrome photoequilibria in the internode is enhanced by blue light perceived by the leaves. Planta $176: 277-282$.

Cosgrove, D. J. 1981. Rapid suppression of growth by blue light : Occurrence, time course, and general characteristics. Plant Physiol. 67 : 584-590.

Gaba, V., Black, M., Attridge, T. H. 1984. Photocontrol of hypocotyl elongation in de-etiolated Cucumis sativus L. Long-term, fluence-rate-dependent responses to blue light. Plant Physiol. $74: 897$ 
-900 .

Gaba, V., Black, M. 1985. Photocontrol of hypocotyl elongation in light-grown Cucumis sativus L. Responses to phytochrome photostationary state and fluence rate. Plant Physiol. 79: 1011-1014.

Hanyu, H., Shoji, K. 1995. Effects of enriching far-red light on growth of kidney beans-Growth responses of a pole type cultivar-. (Japanese text with English abstract) Abiko Res. Lab. Rep. U94049 : 1-15.

Hanyu, H., Shoji, K., Ji, S. -B. 1996. Evaluation of light quality variation through supplement of far-red light and the difference in the effects on growth of a pole-type and bush-type kidney bean, Phaseolus vulgaris L. (Japanese text with English abstract) Environ. Control in Biol. 34: 267-275.

Hsiao, T. C., Allaway, W. G., Evans, L. T. 1973. Action spectra for guard cell Rb+ uptake and stomatal opening in Vicia faba. Plant Physiol. 51 : 82-88.

Holmes, M. G., Schäfer, E. 1981. Action spectra for changes in the "High Irradiance Reaction" in hypocotyls of Sinapis alba L. Planta 153 : 267-272.

Holmgren, P. 1968. Leaf factors affecting light-saturated photosynthesis in ecotypes of Solidago virgaurea from exposed and shaded habitats. Physiol. Plant. 21 : 676-698.

Hughes, J. E., Heathcote, L., Bambridge, K., Black, C. R. 1984. A growth cabinet providing variable spectral photon distributions at high fluence rate. New Phytol. 98 : 211-219

Jose, A. M. 1977. Photoreception and photoresponses in the radish hypocotyl. Planta 136 : 125-129.

Kelly, J. M., Lagarias, J. C. 1985. Photochemistry of 124-kilodalton Avena phytochrome under constant illumination in vitro. Biochemistry $24: 6003-6010$.

Kiegel, J., Cosgrove, D. J. 1991. Photoinhibition of stem elongation by blue and red light. Effects on hydraulic and cell wall properties. Plant Physiol. 95 : 1049-1056.

Lagarias, J. C., Kelly, J. M., Cyr, K. L., Smith, W. O. 1987. Comparative photochemical analysis of highly purified 124-kilodalton oat and rye phytochromes in vitro. Photochem. Photobiol. 46: 5-13.

Lipson, E. D., Galland, P., Pollock, J. A. 1984. Blue light receptors in Phycomyces investigated by action spectroscopy, fluorescence lifetime spectroscopy, and two-dimensional gel electrophoresis. In "Blue Light Effects in Biological Systems" (ed. by Senger, H.). Springer-Verlag, Berlin, p 228-236.

Maas, F. M., Bakx, E. J., Morris, D. A. 1995. Photocontrol of stem elongation and dry weight partitioning in Phaseolus vulgaris L. by the blue-light content of photosynthetic photon flux. J. Plant Physiol. 146: $665-671$.

MacLaren, J. S., Smith, H. 1978. Phytochrome control of the growth and development of Rumex obtusifolius under simulated canopy light environments. Plant Cell Environ. 1 : 61-67.

Mohr, H. 1994. Coaction between pigment systems. In "Photomorphogenesis in Plants" (ed. by Kendrick, R. E., Kronenberg, G. H. M.), Ed. 2. Kluwer Academic Publishers, Dordrecht, p 353-372.

Mortensen, L. M., Str $\phi$ mme, E. 1987. Effects of light quality on some greenhouse crops. Sci. Hortic. 33 : 27-36.

Murakami, K., Horaguchi, K., Morita, M., Aiga, I. 1991. Growth control of the sunflower (Helianthus annus L. cv. Russian Mammoth) seedlings by additional far-red irradiation. (Japanese text with English abstract) Environ. Control in Biol. 29: 73-79.

Rajapakse, N. C., Kelly, J. W. 1995. Spectral filters and growing season influence growth and carbohydrate status of Chrysanthemum. J. Am. Soc. Hortic. Sci. 120 : 78-83.

Ritter, A., Wagner, E., Holmes, M. G. 1981. Light quantity and quality interactions in the control of elongation growth in light grown Chenopodium rubrum L. seedlings. Planta 153 : 556-560.

Robin, C., Varlet-Grancher, C., Gastal, F., Flenet, F., Guckert, A. 1992. Photomorphogenesis of white clover (Trifolium repens L.) : phytochrome mediated effects on ${ }^{14} \mathrm{C}$-assimilate partitioning. Eur. J. Agron. 1 : 235-240.

Simes, D. A., Pearcy, R. W. 1994. Scaling sun and shade photosynthetic acclimation of Alocasia macrorrhiza to whole-plant performance- I. Carbon balance and allocation at different daily photon flux densities. Plant Cell Environ. $17: 881-887$.

Smith, H. 1982. Light quality, photoperception and plant strategy. Annu. Rev. Plant Physiol. 33 : 481 518.

Sung, I. K., Takano, T. 1997. Effects of supplemental lighting blue- and red-lights in the morning twilight on the growth and physiological response of cucumber seedlings. (Japanese text with English abstract) Environ. Control in Biol. 35 : 261-265.

Takano, T. 1975. On the spectral distribution of sunlight and light transmitted into greenhouses. Sci. 
Rep. Fac. Agric., Meijo Univ. 11 : 6-13.

Thomas, B., Dickinson, H. G. 1979 . Evidence for two photoreceptors controlling growth in de-etiolated seedlings. Planta 146 : 545-550.

Warrington, I. J., Michell, K. J. 1976. The influence of blue- and red-based light spectra on the growth and development of plants. Agric. Meteorol. $16: 247-262$.

Wheeler, R. M., Mackowaik, C. L., Sager, J. C. 1991. Soybean stem growth under high-pressure sodium with supplemental blue lighting. Agron. J. 83 : 903-906.

\section{〈和文抄録〉}

\section{単色的光源の混合光下で育成したインゲンマメに及ぼす青色光と赤色光の影響}

\section{羽生広道・庄子和博}

\section{（財）電力中央研究所応用生物部}

青色光と赤色光のレベルの異なる幅広いスペクトル光の下でインゲンマメを 12 日間育成した. 4 種類の単色的蛍光ランプを用いて, 等しい光合成有効光量子束密度 $\left(100 \mu \mathrm{mol} \mathrm{m}^{-2} \mathrm{~s}^{-1}\right)$ および $\mathrm{R}$ : FR 比 (1.1) の下で, 青色光と赤色光を増やした. 青色光と赤色光が増加すると, ともに全乾物量 が増加したが, 乾物分配への影響は全く異なった. 青色光を増やすと, 葉面積への影響は認められ ず, 茎長は大きく減少した.これに対して赤色光を増やすと, 葉面積が増加し茎長も小さいが一貫 して増加した.このことは, 全乾物量の増加は青色光が増加した場合には単位葉面積当たり乾物生 産の増加によるが, 赤色光が増加した場合には葉面積の増加によることを示唆する. 以上の結果 は, R : FR 比によって起こる生長応答に加えて, 青色光の増加が大きな茎の伸長抑制と葉厚の増 加を引き起こし, R : FR 比が一定での赤色光の増加が葉厚を変えることなく葉の伸張と茎の伸長 の両方を促進することを示している. 